Original Article

\title{
IN VITRO ANTIUROLITHIATIC ACTIVITY OF MACERATED AQUEOUS EXTRACT OF TERMINALIA BELERICA BY USING TURBIDITY METHOD
}

\author{
ANU V. ${ }^{*}$, AKHILA S., SNEHA ANTONY \\ Department of Pharmacognosy, KVM College of Pharmacy, Kokkothamangalam, Cherthala, Alappuzha, Kerala, India 688527 \\ Email: anumpharm28@gmail.com
}

Received: 18 Sep 2020, Revised and Accepted: 19 Nov 2020

\begin{abstract}
Objective: To evaluate the anti-urolithiatic activity of macerated aqueous extract of Terminalia belerica by using turbidity method

Method: The present study was used to study the inhibitory effect of the Terminalia belerica on urinary stone formation. The aim of study was to examine the In vitro antiurolithiatic activity of macerated aqueous extract of T.belerica was to estimate inhibitory activity of aqueous extract on the formation of urinary stone. Cystone was used as a positive control. Anti urolithiatic study was performed by turbidity method.

Result: The percentage inhibition shown by aqueous extract at $20 \mu \mathrm{g} / \mathrm{ml}$ was $60 \%$ and with almost constant inhibition at $100 \mu \mathrm{g} / \mathrm{ml}$ and $200 \mu \mathrm{g} / \mathrm{ml}$ ranging between $72 \%$ and $80 \%$. The percentage inhibition showed by aqueous extract of Terminalia belerica has significant compared to standard
\end{abstract} drug.

Conclusion: In future this drug can be performed in vitro and clinical study beneficial for people with avoiding adverse effect of modern medicinal drugs

Key words: antiurolithiatic activity, aqueous extract, Terminalia belerica, cystone,

(C) 2021 The Authors. Published by Innovare Academic Sciences Pvt Ltd. This is an open access article under the CC BY license (https://creativecommons.org/licenses/by/4.0/) DOI: https://dx.doi.org/10.22159/ijcpr.2021v13i1.40824. Journal homepage: https://innovareacademics.in/journals/index.php/ijcpr

\section{INTRODUCTION}

Medicinal plants are widely used in non-industrialized societies, mainly because they are readily available and cheaper than modern medicines. The place of plants in medicine was radically altered in the $19^{\text {th }}$ century by the application of chemical analysis. As chemistry progressed, additional classes of pharmacologically active substances were discovered in medicinal plants. In modern medicine, around a quarter of the drugs prescribed to patients are derived from medicinal plants, and they are rigorously tested. In other systems of medicine, medicinal plants may constitute the majority of what are often informal attempted treatments, not tested scientifically. The World Health Organization estimates, without reliable data, that some 80 percent of the world's population depends mainly on traditional medicine; perhaps some 2 billion people are largely reliant on medicinal plants. The use of plant-based materials, including herbal or natural health products with supposed health benefits, is increasing in developed countries. Herbal medicines have been in use since long before modern medicine existed; there was and often still is little or no knowledge of the pharmacological basis of their actions, if any or of their safety.

Nephrolithiasis or renal stone formation in the kidney is one of the oldest and most widespread diseases known to man. In India people living in different states utilize different plants for curing urolithiasis. Urolithiasis is derived from the Greek words "ouron" (urine) and "lithos"(stone). It is considered as the third most common affliction of the urinary tract6. Urolithiasis is the deposition of formation of stones in any part of the kidney like ureters or the urinary bladder [1, 2].

Urine is normally supersaturated with most stone-forming salt components, as well as contains chemicals that prevent or inhibit crystal development in urinary tract. However, the presence of certain molecules raise the level of supersaturation of salts needed to initiate crystal nucleation or reduce the rate of crystal growth or aggregation and prevents stone formation calcium oxalate stones represent up to $80 \%$ of analyzed stones. Calcium phosphate account for $15-25 \%$, while $10-15 \%$ is mixed stones. The others are struvite $15-30 \%$, cystine $6-10 \%$, and uric acid stones $2-10 \%$ [3-5].

Urolithiasis in its different forms, is frequently encountered during urological complications. Some common causes are inadequate urinary drainage, foreign bodies in the urinary tract, Microbial infections, Diet with excess oxalate and calcium, Vitamin abnormalities, Viz. Vitamin A deficiencies, Vitamin D excess, Metabolic disease like Hyperparathyroidism, Cystinuria, Gout and intestinal dysfunction [6]. Generally, stones of two type's i.e. non calcium and calcium stones are formed [7]. Calcium, Albumin, Creatinine, Urate and oxalate are some necessary analytical markers in serum and urine for clinical diagnosis of this type of urological disorders [8-10].

Terminalia belerica is a well-known medicinal plant and one of the ingredients of popular Ayurvedic formulation "Triphala". It contains numerous phytoconstituents such as Gallo-Tannic acid, bellericanin, ellagic acid, Gallic acid, termilignan, flavones and anolignan B, Tannins, Galloyl glucose and chebulaginic acid, phenyllemblin, mannitol, glucose, Fructose and rhamnose, flavanoids and Saponin. These constituents were responsible for its various pharmacological activities like antioxidant, antimicrobial, anti-diarrheal, antidiabetic, antihypertensive, antispasmodic, bronchodilatory, hepatoprotective, anticarcinogenic and anti-mutagenic properties [11-13].

In Indian traditional system of medicine the plant has been used in the treatment of gall bladder and urinary stone since many years. but its activity has not been reported previously. To justify the ancient and traditional practice of utilizing this plant in renal calculi this research work has been carried out. Therefore, the aim of present study was to examine the in vitro antiurolithiatic activity of Macerated Terminalia belerica Roxb. (Fam. Combretaceae) using aqueous extract by using turbidity method $[14,15]$.

\section{MATERIALS AND METHODS}

\section{Plant material}

The Fruits were collected from the nearby licensed crude drug distributors.

\section{Preparation of plant extracts [16]}

The washed and dried crude drug and performed crushing to coarse powdered form Terminalia belerica fresh core collected and size was reduced by mechanical grinding and passed through sieves. 
Maceration process involves the separation of medicinally active portions of crude drugs, Based on the immersion of crude drug in a bulk of solvent or menstruum. Solid drug material taken in a stoppered container with about $750 \mathrm{ml}$ of menstruum and allowed to stand for at least 3-7 d in a warm place with frequent shaking. The mixture of crude drug-containing solvent is filtered until most of liquid drains off. The filtrate and washing are combined to produce $1000 \mathrm{ml}$ of the solution.

Coarse Solid drug material taken in a stoppered container with about $750 \mathrm{ml}$ of Menstruum and allowed to stand for at least 3-7 d in a warm place with frequent shaking. The mixture of crude drugcontaining solvent is filtered until most of liquid drains off. The filtrate and washing are combined to produce $1000 \mathrm{ml}$ of the solution. The crude drug material is charged in the extractor, which is connected with a circulatory pump and spray distributor, along with number of connected tanks to receive the extraction solution. This is known as multiple stage extraction because the solvent added and circulated in the extractor containing drug is removed as extracted solution and is stored in the receiver tanks. This operation is repeated thrice. When the crude drug material is charged in the extractions, the stored solution is once again circulated through fresh drug and then removed as an extract. Likewise, after three extractions, the drug and removed from the extractor, again recharged with fresh drug and the whole cycle is repeated in vitro antiurolithiatic activity [17]

The effects of Terminalia belerica extracts on calcium oxalate crystallization was determined by the time course measurement of turbidity changes due to the crystal nucleation and aggregation in the Human urine on the addition of $0.01 \mathrm{M}$ sodium oxalate. The precipitation of calcium oxalate at $370 \mathrm{C}$ and $\mathrm{pH} 6.8$ has been studied by the measurement of turbidity at $620 \mathrm{~nm}$. A spectrophotometer
UV/Vis was employed to measure the turbidity of the formation of calcium oxalate.

\section{Study without inhibitor}

A volume of $1 \mathrm{ml}$ of human urine was transferred into the cell and $0.5 \mathrm{ml}$ of distilled water to it and blank reading was taken. $0.5 \mathrm{ml}$ of $0.01 \mathrm{M}$ sodium oxalate was added to the previous volume, and the measurement is immediately started for a period of $400 \mathrm{sec} 28$.

\section{Study with inhibitor}

Extract was re-suspended in distilled water filtered and used at a final concentration of 20,100 and $200 \mathrm{mg} / 0.5 \mathrm{ml}$ were prepared. A mixture of $1 \mathrm{ml}$ human urine and $0.5 \mathrm{ml}$ of plant extract solution is versed in the cell. A blank reading was taken and then the volume of $0.5 \mathrm{ml}$ of $0.01 \mathrm{M}$ sodium oxalate was added and the measurement is immediately started for a period of $400 \mathrm{sec}$. The percentage of inhibition was calculated using the following formula

$$
\% \text { inhibition }=\{1-[\mathrm{Si} / \mathrm{Sc}]\} \times 100
$$

Where; Si: slope of graph in the presence of inhibitor (Plant extract)

Sc: slope of graph without inhibitor (control)

\section{RESULTS AND DISCUSSION}

\section{In vitro anti urolithiatic study}

Percentage inhibition of the crystallization of calcium oxalate $(\mathrm{CaOx})$ with different concentrations of aqueous extract of $T$. bellerica. It inhibited the crystallization in a concentration-dependent pattern. The percentage inhibition shown by aqueous extract at $20 \mu \mathrm{g} / \mathrm{ml}$ was $60 \%$ and with almost constant inhibition at $100 \mu \mathrm{g} / \mathrm{ml}$ and 200 $\mu \mathrm{g} / \mathrm{ml}$ is ranging between $72-80 \%$. Absorbance vs Time of with inhibitor and without inhibitor shown below.

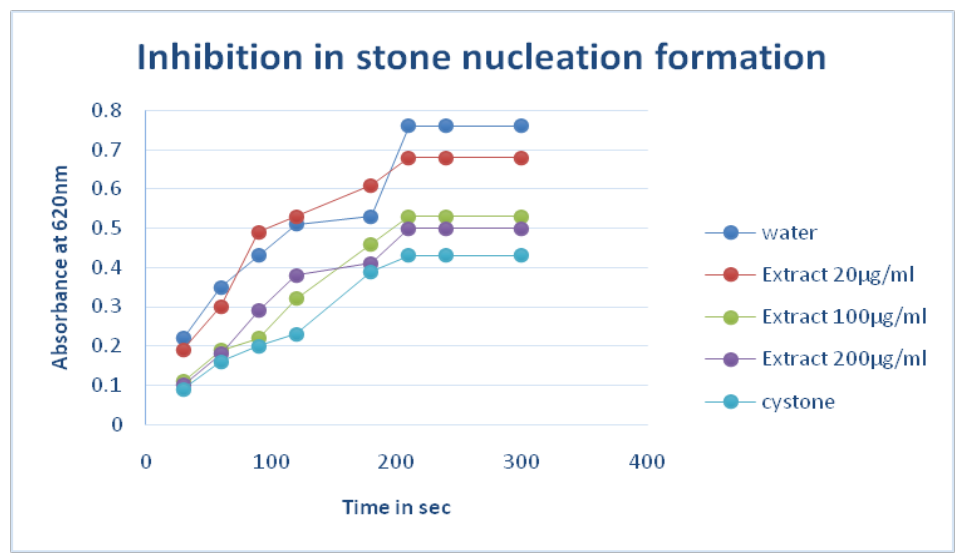

Fig. 1: Graph showing the inhibition in the stone nucleation formation with and without plant extract. Cystone as positive controls

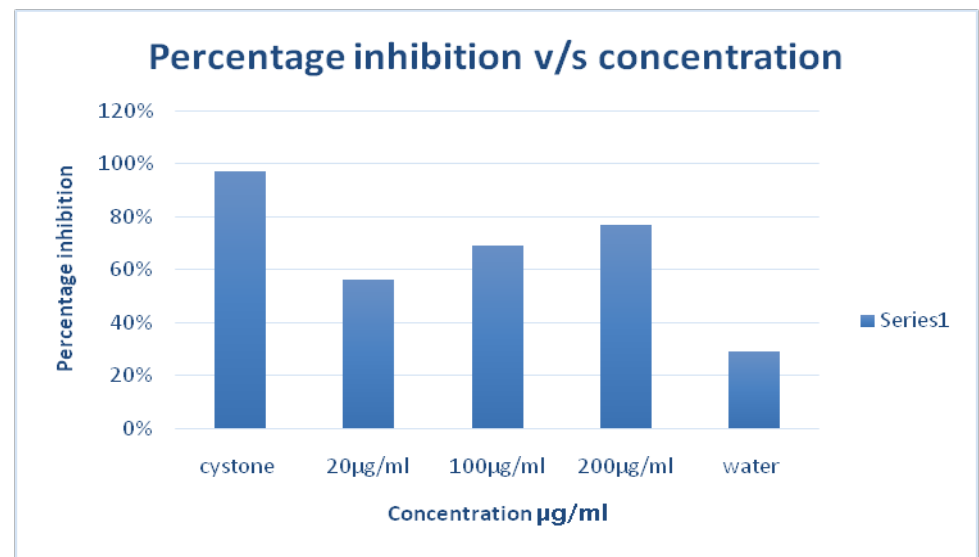

Fig. 2: The percentage inhibition of calcium oxalate of different concentration of aqueous extract of Terminalia belerica 


\section{CONCLUSION}

Many of the Terminalia species have been reported for antiurolithiatic activity. Fruits of Terminalia belerica for this study. Qualitative chemical test showed Alkaloid, Flavanoids, Steroids, Phenols, Saponins and Carbohydrates. The turbidity method has showed extremely significant action on urinary caliculi. Turbidiometric method measures the turbidity in terms of calcium oxalate formation in human urine using a spectrophotometer at $620 \mathrm{~nm}$ and crystallization inhibition measured by turbidity reduction. The percentage of inhibition showed by aqueous extract of Terminalia belerica has significant compared to standard drug. In future this drug can be performed In vivo and clinical study beneficial for people with avoiding adverse effects of modern medicinal drugs.

\section{ACKNOWLEDGEMENT}

We sincerely thankful to our principal Dr. Preeja G Pillai, Dr. Akhila S, Head of Department of Pharmacognosy of our college KVM College of Pharmacy, Cherthala, Alappuzha, Kerala for supporting us

\section{FUNDING}

Nil

\section{AUTHORS CONTRIBUTIONS}

All the authors have contributed equally.

\section{CONFLICT OF INTERESTS}

Nil

\section{REFERENCES}

1. Chitme HR, Shashi A, Jain SK, Sabharwal M. Herbal treatmenr for urinary stones. Int J Pharm Sci Res 2010;1:25:31.

2. Khan MA, Pradhan D. Antiurolithiatic activity of ceropegia bulbosa extract in rats. Der Pharm Sin 2013;3:148-52.

3. Singh SK. Disease monograph-5; Urolithiasis; central council for research in homeopathy publication. Deluex Printery; 2011. p. 4.

4. Awari MD, Mute V, Babhale SP, Chaudhar PS. Antilithiatic effect of achyranthesaspera linn. leaves extract on ethylene glycol induced nephrolithiasis. J Pharm Res 2009;2:994-7.
5. Shashi A, Jain SK, Verma A, Kumar M, Sabharwal M. Pathophysiology of kidney. gallbladder and urinary stones treatment with herbal and allopathic medicine; a review. Asian Pac J Trop Dis 2013;3:496-504.

6. Tiselius HG. Etiology and investigation of stone disease, curriculum in urology. Eur Urol 1998;2:1-7.

7. Mistry J, Danpure CJ, Chalmers RA. Hepatic D-glycerates dehydrogenase and glyoxylate reductase deficieny in primary hyperoxaluria type 2. Biochem Soc Trans 1988;16:626-7.

8. Hobarth K, Hofbauer J, Szabo N. Value of repeated analysis of $24 \mathrm{~h}$ urine in recurrent calsiumurolythyasis. Urology 1994;44:20-5

9. Hess B, Hasler Strub U, Askermann D, Jaeger PH. Metabolic evalulationn of patient with recurrent idiopathic calcium nephrolithiasis. Nephrol Dial Transplant 1997;12:1362-8.

10. Tiselius HG. Solution chemistry of supersatutartion. In: Kidney Stone: Medical and Surgical Management. FL Coe, MJ Favus, CYC Pak, HG Parks, GM Preminger. (Eds) Lippincott-Raven Publishers, Philadelphia; 1996. p. 31, 33-64.

11. Khan AU, Gilani AH. Pharmacodynamic evaluation of terminalia bellirica for its antihypertensive effect. J Food Drug Anal 2008;16:6-14.

12. Kaur S, Jaggi RK. Antinociceptive activity of chronic administration of different extracts of Terminalia bellirica roxb and terminaliachebula retz. Fruits Indian J Exp Biol 2010;48:925-30.

13. Saraswathi MN, Karthikeyan M, Kannan M, Rajasekar S, Terminalia Bellirica. Roxb-a phytopharmacological review. Int J Res Pharm Biomed Sci 2012;3:96-9.

14. Frawley D, Vasant L. The yoga of herbs: an ayurvedic guide to herbal medicine. Santa Fe: Lotus Press; 1986.

15. Selvan AT, Jayalaxmi B, Ashvini RP, Suthakaran R, Vishwanath Antiurolithiatic activity of triphalakarpachooranam. J Adv Pharm Edu Res 2013;3:267-72.

16. Anu V, Pavithra P. In vitro anthelmintic activity of macerated ethanolic extracts of roots of holostema adakodien. Int J Pharmacogn 2019;6:30-2.

17. Bensatal A, OUahrani MR. Inhibition of crystalisation of calcium oxalate by the extraction of tamarixgallica L. Urol Res 2008;36:283-7. 